Article

\title{
Pragmatism as a Research Paradigm and Its Implications for Social Work Research
}

\author{
Vibha Kaushik * and Christine A. Walsh \\ Faculty of Social Work, University of Calgary, Calgary, AB T2N 1N4, Canada \\ * Correspondence: vkaushik@ucalgary.ca
}

Received: 18 July 2019; Accepted: 3 September 2019; Published: 6 September 2019

\begin{abstract}
Debates around the issues of knowledge of, and for, social work and other social justice-oriented professions are not uncommon. More prevalent are the discussions around the ways by which social work knowledge is obtained. In recent years, social work scholars have drawn on the epistemology of pragmatism to present a case for its value in the creation of knowledge for social work and other social justice-oriented professions. The primary focus of this essay is on providing a critical review and synthesis of the literature regarding pragmatism as a research paradigm. In this essay, we analyze the major philosophical underpinnings and methodological challenges associated with pragmatism, synthesize the works of scholars who have contributed to the understanding of pragmatism as a research paradigm, articulate our thoughts about how pragmatism fits within social work research, and illustrate how it is linked to the pursuit of social justice. This article brings together a variety of perspectives to argue that pragmatism has the potential to closely engage and empower marginalized and oppressed communities and provide hard evidence for the macro level discourse.
\end{abstract}

Keywords: pragmatism; pragmatic research; social justice research; social work research

\section{Introduction}

In social research, the term "paradigm" is used to refer to the philosophical assumptions or to the basic set of beliefs that guide the actions and define the worldview of the researcher (Lincoln et al. 2011). Introduced by Thomas Kuhn (1970), the term paradigm was used to discuss the shared generalizations, beliefs, and values of a community of specialists regarding the nature of reality and knowledge. "Worldview," as a synonym for paradigm (see Creswell and Clark 2011; Lincoln 1990; Patton 2002; Rossman and Rallis 2003), is described as "a way of thinking about and making sense of the complexities of the real world" (Patton 2002, p. 69). Although there are several paradigms or worldviews that structure and organize modern social work research (e.g., postpositivism, constructivism, participatory action frameworks, or pragmatism), they are all essentially philosophical in nature and encompass the following common elements: axiology—beliefs about the role of values and morals in research; ontology-assumptions about the nature of reality; epistemology-assumptions about how we know the world, how we gain knowledge, the relationship between the knower and the known; methodology - shared understanding of best means for gaining knowledge about the world; and rhetoric-shared understanding of the language of research (Creswell 2009; Lincoln et al. 2011).

Paradigms are conceptual and practical "tools" that are used to solve specific research problems; in other words, paradigms function as heuristics in social research (Abbott 2004, p. 42). Each paradigm has a different perspective on the axiology, ontology, epistemology, methodology, and rhetoric of research. In brief, for instance, postpositivism, one of the older approaches of social research, is often associated with quantitative methods and highly formal rhetoric which focuses on precision, generalizability, reliability, and replicability. Postpositivist researchers view inquiry as a series of logically related steps and make claims of knowledge based on objectivity, standardization, deductive reasoning, and control 
within the research process (Creswell 2013; Creswell and Clark 2011; Lanham 2006). Constructivism is typically associated with qualitative methods and literary and informal rhetoric in which the researcher relies as much as possible on the participants' view and develops subjective meanings of the phenomena. Thus, constructivist research is shaped from the bottom up, i.e., from individual perspectives, to broad patterns, and ultimately to broad understandings (Creswell and Clark 2011). If we situate postpositivist and constructivist research on a paradigm continuum, they will be anchored on its two opposite ends (Betzner 2008). Unlike the fundamental underpinnings of these worldviews, participatory action research is conducted with an agenda of reform and empowerment, i.e., the focus is on transforming the lives of socially marginalized populations. It is a collaborative approach in which participants are involved at each step of research. Participatory action research is often associated with qualitative methods and rhetoric of advocacy and change (Creswell 2013; Creswell and Clark 2011). Finally, pragmatism is a paradigm that claims to bridge the gap between the scientific method and structuralist orientation of older approaches and the naturalistic methods and freewheeling orientation of newer approaches (Creswell 2013; Creswell and Clark 2011).

Debates around the issues of knowledge of-and for-social work and other social justice-oriented professions are not uncommon. More prevalent are the discussions around the ways by which the social work knowledge is obtained. In recent years, social work scholars have drawn on the philosophical analysis of pragmatism to present a case for its value in the creation of knowledge for social work and other social justice-oriented professions. Therefore, the primary focus of this essay is on providing a critical review and synthesis of the literature regarding pragmatism as a research paradigm. Our goal is fourfold: to analyze the major philosophical underpinnings and methodological challenges associated with pragmatism; to synthesize the works of scholars who studied the philosophical ideas of pragmatism, analyzed the works of Dewey and other primary figures associated with pragmatism, and contributed to the understanding of pragmatism as a research paradigm; to articulate our thoughts about how pragmatism fits within social work research; and to illustrate how it is linked to the pursuit of social justice.

\section{History and Ideas of Pragmatism}

Pragmatism as a research paradigm finds its philosophical foundation in the historical contributions of the philosophy of pragmatism (Maxcy 2003) and, as such, embraces plurality of methods. As a research paradigm, pragmatism is based on the proposition that researchers should use the philosophical and/or methodological approach that works best for the particular research problem that is being investigated (Tashakkori and Teddlie 1998). It is often associated with mixed-methods or multiple-methods (see Biesta 2010; Creswell and Clark 2011; Johnson and Onwuegbuzie 2004; Maxcy 2003; Morgan 2014a; Teddlie and Tashakkori 2009), where the focus is on the consequences of research and on the research questions rather than on the methods. It may employ both formal or informal rhetoric (Creswell and Clark 2011).

As a philosophical movement, pragmatism originated in the late 19th century in the United States (Maxcy 2003). This distinctly American philosophical doctrine is traced back to a discussion group in Cambridge, Massachusetts in the early 1870s, which brought together the founding fathers of pragmatism including the philosopher Charles Sanders Peirce, psychologist William James, philosopher and mathematician Chauncey Wright, jurist Oliver Wendell Holmes Jr., and philosopher and lawyer Nicholas St. Johns Green. Philosopher, educationist and social reformer John Dewey; philosopher, sociologist, and psychologist George Herbert Mead; philosopher and political scientist Arthur F. Bentley; and countless other academics and non-academics further developed the doctrine over the past century (Maxcy 2003; Morgan 2014a; Pansiri 2005; Ormerod 2006). The philosophical movement of pragmatism began as a consequence of the fundamental agreement of these scholars over the rejection of traditional assumptions about the nature of reality, knowledge, and inquiry. The pragmatist scholars completely rejected the notion that social science inquiry can access the reality solely by using a single scientific method (Maxcy 2003). 
The term pragmatism was first used by William James in 1898 in a public speech; however, he acknowledged in his speech that his source of pragmatic philosophy was Charles Sanders Pierce, who himself borrowed the word "pragmatic" from Kant's Kritik der reinen Vernunft (Critique of pure reasons). Nonetheless, it was Richard Rorty who took the term from the philosophical circles and introduced it to a larger audience in 1979 as an American research vocabulary (Maxcy 2003; Ormerod 2006).

The word pragmatism is originally derived from the Greek word "pragma," which means action, and which is the central concept of pragmatism (Pansiri 2005). Pragmatist philosophy holds that human actions can never be separated from the past experiences and from the beliefs that have originated from those experiences. Human thoughts are thus intrinsically linked to action. People take actions based on the possible consequences of their action, and they use the results of their actions to predict the consequences of similar actions in the future. A major contention of pragmatist philosophy is that meaning of human actions and beliefs is found in their consequences. External forces do not determine humans; they are themselves capable of shaping their experience through their actions and intelligence. Pragmatists believe that reality is not static-it changes at every turn of events. Similarly, the world is also not static-it is in a constant state of becoming. The world is also changed through actions-action is the way to change existence. Actions have the role of an intermediary. Therefore, actions are pivotal in pragmatism (Goldkuhl 2012; Maxcy 2003; Morgan 2014a).

Morgan (2014a), who uses the work of John Dewey to develop his approach to pragmatism, identifies three widely shared ideas of pragmatism that highlight that pragmatists focus on the nature of experience unlike other philosophies that emphasize nature of reality. First, "actions cannot be separated from the situations and contexts in which they occur" (p. 26). This world is a world of unique human experiences in which, instead of universal truths, there are warranted beliefs, which take shape as we repeatedly take actions in similar situations and experience the outcomes. Our warranted beliefs are produced by the repeated experiences of predictable outcomes (Morgan 2014a). Second, "actions are linked to consequences in ways that are open to change" (p. 26), meaning that, if the situations of the action change, their consequences would also change, despite the actions being the same. Pragmatist philosophy maintains that it is not possible to experience exactly the same situation twice, so our warranted beliefs about the possible outcome are also provisional, which means that our beliefs about how to act in a situation are inherently provisional (Morgan 2014a). Finally, "actions depend on worldviews that are socially shared sets of beliefs" (p. 27). Pragmatists believe that no two people have exactly identical experiences, so their worldviews can also not be identical. However, there are always varying degrees of shared experiences between any two people that lead to different degrees of shared beliefs. The likelihood of acting in the same way in a similar situation and assigning similar meanings to the consequences of those actions depends on the extent of shared belief about that particular situation. Therefore, worldviews can be both individually unique and socially shared (Morgan 2014a).

\section{Pragmatism as a Research Paradigm}

Pragmatism as a research paradigm refuses to get involved in the contentious metaphysical concepts such as truth and reality. Instead, it accepts that there can be single or multiple realities that are open to empirical inquiry (Creswell and Clark 2011). Pragmatist scholars have offered their particular opinion that there is an objective reality that exists apart from human experience. However, this reality is grounded in the environment and can only be encountered through human experience (Goles and Hirschheim 2000; Morgan 2014a; Tashakkori and Teddlie 2008). A major underpinning of pragmatist philosophy is that knowledge and reality are based on beliefs and habits that are socially constructed (Yefimov 2004). Pragmatists generally agree that all knowledge in this world is socially constructed, but some versions of those social constructions match individuals' experiences more than others (Morgan 2014a).

Pragmatists doubt that reality can ever be determined once and for all (Pansiri 2005). They view reality as a normative concept and maintain that reality is what works. Therefore, they argue 
that knowledge claims cannot be totally abstracted from contingent beliefs, habits, and experiences (Howe 1988). For pragmatists, reality is true as far as it helps us to get into satisfactory relations with other parts of our experiences (James 2000). Truth is whatever proves itself good or what has stood the scrutiny of individual use over time (Baker and Schaltegger 2015; James 2000; Ray 2004). However, there is a need to remember that pragmatism does not simply mean that "if it works then it's true (Boisvert 1998, p. 31). Pragmatist researchers do not simply push aside philosophical arguments, particularly the metaphysical arguments, to get their research done. Rather, they have come to a conclusion, after careful consideration of the effort and involvement, that the broader philosophical arguments can never be solved. Why? Because, meaning is inseparable from human experience and needs and is dependent upon context (Dillon et al. 2000).

Pragmatist researchers' choice of one version of reality over another is governed by how well that choice results in anticipated or desired outcomes (Tashakkori and Teddlie 2008). Goles and Hirschheim (2000) elaborate on this with the following example: For a more positivistic researcher, an object with flat surface and four legs would always be a table. For a constructivist, based on her/his perspective, the same object would be a table if $\mathrm{s} /$ he was eating off it, a bench if $\mathrm{s} / \mathrm{he}$ was sitting on it, and a platform if $\mathrm{s} /$ he was standing on it. However, a pragmatist would define the object based on its utility, for instance, the object would be a table if s/he intends to eat off it, a bench if s/he intends to sit on it, and a platform if $s /$ he intends to stand on it. In this example, it is important to notice that the pragmatist would not define the object based on what it is or what it is being used for, but rather based on how it would help the pragmatist achieve her/his purpose (Goles and Hirschheim 2000, p. 261). Pragmatists believe that we are free to believe anything that we want, although some beliefs are more likely than others to meet our goals and needs (Morgan 2014a).

Biesta (2010) reminds us to not to merely understand pragmatism as a philosophical position but rather as a set of philosophical tools of value for addressing problems. As a research paradigm, pragmatism orients itself toward solving practical problems in the real world. It emerged as a method of inquiry for more practical-minded researchers (Creswell and Clark 2011; Maxcy 2003; Rorty 2000). For pragmatists, an inquiry - in both social life and social work research-is effective only if it achieves its purposes (Hothersall 2019). Pragmatism rejects traditional philosophical dualism of objectivity and subjectivity (Biesta 2010), and allows the researcher to abandon the forced dichotomies which are postpositivism and constructivism (Creswell and Clark 2011). In pragmatism, empirical is preferred over idealistic or rationalistic approaches (Frega 2011). Rather than assigning postpositivism and constructivism in two different ontological and epistemological camps, pragmatism ask the researcher to focus on the two different approaches to inquiry (Morgan 2014b).

\subsection{Philosophical Underpinnings of Pragmatism}

A major underpinning of pragmatist epistemology is that knowledge is always based on experience. One's perceptions of the world are influenced by our social experiences. Each person's knowledge is unique as it is created by her/his unique experiences. Nevertheless, much of this knowledge is socially shared as it is created from socially shared experiences. Therefore, all knowledge is social knowledge (Morgan 2014a). Pragmatist epistemology does not view knowledge as reality (Rorty 1980). Rather, it is constructed with a purpose to better manage one's existence and to take part in the world (Goldkuhl 2012).

Several leading pragmatist scholars have studied the works of Dewey and offered their view that epistemology essentially draws from Dewey's concept of inquiry which links beliefs and actions through a process of inquiry (see Biesta 2010; Feilzer 2010; Goldkuhl 2012; Morgan 2014a; Ormerod 2006). John Dewey was a great thinker and practitioner well known for his achievements in the development of social work in the United States (Koenig et al. 2019; Thompson 2012). The primary focus of Dewey's philosophical interests was what has been traditionally called "epistemology." However, he rejected the term epistemology and expressly preferred using the term "theory of inquiry." Dewey offered that it was more representative of his own approach to knowledge (Deen 2011; Dewey 1938; 
Mcgilvary et al. 1939). For Dewey (1931, 1938), inquiry is an investigation to understand some part of reality and to create knowledge to bring change in that part of reality. It is a systemization of humans' natural effort to improve their situation. The primary purpose of inquiry is to create knowledge in the interest of change and improvement (Goldkuhl 2012). Dewey defined inquiry as the controlled transformation of a problematic situation into one that is sufficiently integrated with knowledge or coherent action (Ormerod 2006).

Dewey was interested in inquiry as a form of experience that helps to resolve uncertainty and some way supports action (see Biesta 2010; Morgan 2014a). Dewey's inquiry is concerned with understanding the relationship between our actions and their consequences, thereby helping us gain more control over our actions as compared to what we have by using trial and error. By no means does better control over our action means complete mastery. It rather means our ability to plan intelligently and to direct our actions to achieve desired consequences (Biesta 2010). This ability is very important in unsettling situations - ones in which we are not immediately sure how to act. In other words, inquiry is one's conscious response in situations in which the course of action is not immediately clear. In such situations, before taking any action, a pragmatist considers the consequences of different actions and the potential benefits of one action over another (Biesta 2010; Morgan 2014a).

Another of Dewey's concepts that are relevant for pragmatism is the idea of experimental learning or, as Dewey preferred to call it, "habits" (see Biesta 2010). According to Dewey's framework, we, as living organisms, are capable of establishing and maintaining a dynamic coordination with our environment. The process of establishing and maintaining the coordination results in habit formation. Through this process, our habits become more congruent to our ever-changing environment. This is a learning process, basically a process of trial and error, through which we acquire a complex, yet flexible, set of habits for action (Biesta 2010). Habits can adequately handle our demand for action in many situations. Indeed, they occur in a semi-automated state in which much of what we do does not require careful decision making. Inquiry stands in contrast to habit, as it is a self-conscious process of decision making (Morgan 2014b) and choosing intelligent action, rather than blind trial and error, aimed at achieving desired consequences (Biesta 2010). It requires application of intelligent action based on the self-correcting method of hypotheses testing in which hypotheses are created and then refined according to our own previous experiences (Ormerod 2006).

Dewey did not distinguish between everyday inquiry and research; "inquiry [in this proposition] is just one form of experience and research is just one form of inquiry" (Morgan 2014b, p. 1047). In both cases, decision-making would involve evaluation of likely consequences, that is, whether the potential consequences would match or differ from the research goals. The difference between an everyday inquiry and a research then is that research requires a larger amount of careful attention and self-conscious decision making (Morgan 2014a, 2014b). Therefore, while designing a research project, pragmatist researchers in general always consider the various differences that designing and conducting a research project would make (Creswell and Clark 2011; Morgan 2014a). After thinking about the potential consequences of various choices, researchers proceed with their own warranted beliefs about the likely consequences of designing and conducting the research project in a particular way (Morgan 2014a). However, these beliefs are shaped by researchers' previous experiences and are shared by the larger research communities of which the individual researchers are members. The potential consequences of the choice of the methodology can only be evaluated based on the original research question and the goals and purposes of the research project (Morgan 2014a). The overriding issue for pragmatists then is whether the philosophical assumptions, the methodology, or the information is useful and instrumental in producing desired or anticipated results (Goles and Hirschheim 2000). Pragmatist researchers place the research question above such philosophical considerations (Tashakkori and Teddlie 2008). 


\subsection{Methodological Challenges of Pragmatism}

There is a strong tendency among social scientists to not only place heavy emphasis on ontological issues but also to privilege epistemology over methodology (Morgan 2007). Whether epistemological issues should be of major interest to social science researchers is debatable as epistemology is primarily a philosophical field of inquiry. There are arguments that pragmatism should focus on methodology, as methodology is an area that connects abstract philosophical issues to actual mechanical methods. In fact, it has been emphasized that pragmatist researchers should study both, that is methodology, which is related to research itself, and epistemology, which are the warranted beliefs that influence how we conduct our research. It is important to focus on methodology as a tool to connect our thoughts about the nature of knowledge from our efforts to produce it rather than separating philosophical threads from the research design (Morgan 2007).

Unlike positivistic researchers, who assert an objective knowledge acquired by examining empirical evidences and hypothesis testing, and constructivists, who propose that knowledge is relative and reality is too complex, pragmatists believe that the process of acquiring knowledge is a continuum rather than two opposing and mutually exclusive poles of either objectivity and subjectivity (Goles and Hirschheim 2000). Thus, pragmatism is situated somewhere in the center of the paradigm continuum in terms of mode of inquiry. Postpositivism typically supports quantitative methods and deductive reasoning, whereas constructivism emphasizes qualitative approaches and inductive reasoning; however, pragmatism embraces the two extremes and offers a flexible and more reflexive approach to research design (Feilzer 2010; Morgan 2007; Pansiri 2005). In adopting this stance, the pragmatist researcher is able to select the research design and the methodology that are most appropriate to address the research question. Pragmatism is typically associated with abductive reasoning that moves back and forth between deduction and induction. In this way, the researcher is actively involved in creating data as well as theories (Goldkuhl 2012; Morgan 2007).

Another important consideration is the aspect of pragmatism that is a part of a researcher's worldview and therefore can influence the way researchers conduct their project. Kuhn's $(1962,1970)$ concept of paradigms has also been explored as a set of shared beliefs among a research community to elaborate on what counts as most important research questions and the most appropriate research methodology (Morgan 2007). This is important as not all research questions are fundamentally important, nor are the methodologies automatically appropriate. Ultimately, it is the researcher who makes the choices and decides which question is important and what methodology is appropriate, and those choices are certainly influenced by the aspects of sociopolitical location of the researcher, his/her personal history, and his/her belief system (Morgan 2007).

Dewey's theory of social inquiry has also been analyzed within the methodological contexts of pragmatism (see Dillon et al. 2000). Dewey suggests that a pragmatist would identify genuine problems that are part of actual social situations, would carefully define them, and then initiate the inquiry to address them. Dewey insists that a research problem is legitimate for inquiry only if it is socially situated, that inquiries are natural, situational, and grounded in problems. Dewey's philosophy holds that inquiries are both interrogations of theory and practice and are also evaluative. Dewey's work has been used to identify the weakness of most inquiries-that is, selecting the methodology without clearly understanding the problem. Dewey recommends that once the problem is identified and the dimensions are clearly defined, the researcher should investigate the problem from various perspectives, depending on the purpose or objective of the inquiry (Dillon et al. 2000).

Critics of pragmatism, however, have noted several practical challenges associated with the identification of a socially situated research problem. For instance, Thompson (1997) pointed out the contextual, problem-centered nature of pragmatism that, according to her, limits its ability to identify and analyze structural social problems. She further illustrates this by using an example in which the focus of inquiry is the below satisfactory performance of girls in a computer class and compared it with the superior performance of boys in the same class. Most likely, in the given situation, the problem will be framed in terms of girls, e.g., "Why are girls reluctant to program?" (p. 426), or "Why do girls as a 
group consistently perform less well than boys, in computer classes?" (p. 426). The problem will not be framed as "Why do boys typically thrive in computer programming classes?" (p. 426), or "How is boys' superior performance in computer classwork related to the historically male-dominated character of academia, the organization of the workplace, or the construction of maleness as not femaleness?" (p. 426). This illustration raises an obvious concern: someone who is a member of dominant social group and who benefits from structural inequality would not necessarily consider hegemonic power structures as problematic and worthy of inquiry (Thompson 1997).

When it comes to translating epistemological concerns into research methodology and finally deciding the research methods, pragmatism raises some methodological concerns. For instance, if a research problem has different layers, how can all the layers be measured or observed (Feilzer 2010)? Certainly, one important strategy for inquiry would be to employ multiple methods, measures, researchers, and perspectives. However, this should be done reasonably and practically (Patton 2002). It has been established that, as a paradigmatic position, pragmatism assumes an independence of methods (Greene and Caracelli 2003; Teddlie and Tashakkori 2009) in which researchers do not have to absolutely commit themselves to a particular research method (Robson 1993). As a result, studies employ diverse methodological combinations to address the research questions, for instance, some studies employ intermixing of interviewing, observation, and document analysis; some studies rely more on interviews rather than observations or vice versa; a large number of studies even employ intermixing of qualitative and quantitative data to address their research question (Patton 2002). In sum, researchers prefer addressing their research questions with any methodological tool available, using the pragmatist credo of "what works." For most researchers committed to the thorough study of a research problem, method is secondary to the research question itself, and the underlying worldview hardly enters the picture, except in the most abstract senses (Tashakkori and Teddlie 1998, p. 21).

In other words, methodologists have begun to use pragmatism to justify their move toward method acceptability (Maxcy 2003). However, it is important to note that, for pragmatists, the best method is the one that is most effective in producing the desired consequences of the inquiry, whether it is a single-method, multiple methods, or a mix of methods (Tashakkori and Teddlie 2008). So, should pragmatism, as a research paradigm, be linked to mixed-methods research? Does pragmatism provide a rationale for mixed-methods research? Some scholars have argued that pragmatism does not provide philosophical foundation for mixed-methods research (see Biesta 2010); instead, it is realism that provides a more valuable perspective for many aspects of mixed-methods research (Maxwell and Mittapalli 2010). Greene (2007) called on researchers to take a dialectic stance to mixed-methods research that would welcome more than one paradigmatic tradition into the space of the same inquiry and engage with all paradigms in a respectful dialogue throughout the inquiry. Others noted that pragmatism does not necessarily require a particular method or mixing methods and definitely does not exclude other methods. Rather, it aims to simply address the research question, investigate a phenomenon, or test a theory with the most appropriate research method (Feilzer 2010). However, there is a general consensus in favor of taking a pragmatic stance for conducting a mixed-methods research. For instance, Teddlie and Tashakkori (2003) have noticed that at least 13 different authors have explicitly advocated the use of pragmatist position in the use of mixed-methods design and that pragmatism is mentioned most often in the mixed-methods literature. Mixed-methods researchers promote pragmatism as a paradigm by suggesting that it is directly linked to the needs of mixed-methods research. Scholars maintain that pragmatism provides philosophical foundation for social science research, in general, and mixed-methods research, in particular (Morgan 2014a).

The foremost argument in favor of pragmatist approach in the matter of mixing quantitative and qualitative research is the significance that pragmatism gives to the research question (Bryman 2006). In this context, there are two issues that are frequently debated. First, it is often suggested that, in pragmatist research, the methodological approach is adopted based on the adequacy of particular methods for answering research questions and not primarily due to the researcher's commitment to a paradigm and the philosophical doctrine on which it is supposedly based (Bryman 2006). This debate 
about the methodological approach prioritizes the research question, sidelines epistemological and ontological arguments, and clears the path for research that combines quantitative and qualitative research (Bryman 2006; Erzberger and Kelle 2003; Teddlie and Tashakkori 2003). Second, the dominance given to the research question in pragmatism means that research that brings together quantitative and qualitative research is feasible, desirable, and also required to address certain research question or certain combinations of research questions (Bryman 2006).

To summarize, as a methodological approach to problem solving, pragmatism requires detection of a socially situated problem and adequate action to address the problem. Dewey (1933) presented a five-step model for understanding problem solving, which was later studied and revised by Morgan (2014a) to illustrate a dynamic system of pragmatist research methodology. The first step of this model involves encountering a situation and recognizing it as a research problem. However, the problem would lie beyond the researcher's current range of experience. Therefore, the researcher would not have any line of action to address the research problem. In the second step, the researcher would reflect on the nature of the problem using her/his existing beliefs. The process of reflecting may sometimes lead to developing new version of the problem and reformulation of research question that was identified in the first step. The third step involves considering possible actions, i.e., thinking about the possible ways to address the research question and the potential research design. At the next stage, the researcher would reflect on the choice of research methods and think about the best methods to address the research question. As a result of this process, the researcher may take a step back, as thinking about the choice of methods may bring the researcher back to revising the choice of research design, which may further bring her/him back to the first step for reconsidering the research question. Before proceeding to step five and conducting the research, the researcher may go through several rounds of designing the research, selecting the methods, reflecting on the choices made, and reconsidering the research question. In pragmatism, this process is called "abduction," which is based on a kind of if-then relationship, in which researchers' reflection on the nature of the problem leads them to conclude that "if you act in a particular way, then you are likely produce a specific set of outcomes (Morgan 2014a, p. 29, emphasis in original). Thus, pragmatist methodology leads to the following forms of reflection: on the nature of the problem and its potential solutions, and on the nature of the potential solutions and the likely actions. In other words, the methodology connects the process of designing the research to the core research question and connects the design concerns to the choice of methods. Thus, research design plays a crucial role of bridging the gap between research questions and research methods. However, it is important to note that as simplistic this step-by-step process appears, it is a complex social system of research in which throughout the process of decision making, the researcher is not only guided by her/his beliefs, by the shared beliefs of the research community, and by the personal experiences, but also learns from the experiences of others (Morgan 2014a, pp. 29-31).

\section{Pragmatism and Social Work Research}

Pragmatism and social work share the central tenet of coming to know this world through experiences and actions. Both share the principle that overt action is necessary in combination with reflection for acquiring knowledge and that our ideas, concepts, and theories can be tested only by our rational actions that follow from them and observing and analyzing the consequences. For pragmatism, practical consequences are not profit-or-gain but are the axial test of epistemic and metaphysical significance. Pragmatism is focused on the future. The consequences of actions are more relevant than the antecedents. In this way, pragmatism supports the core values of the social work profession (Haight and Bidwell 2016; Hothersall 2019). This is exemplified in the body of work produced by the mother of social work and colleague of Dewey, Jane Addams, and is also reflected in the contemporary social work scholarship. Jane Addams was the forbearer of modern social work and was a pioneer in developing and adopting pragmatist philosophy in her work. Addams' work was committed to democracy, freedom, and equality. She philosophized an action-oriented approach to knowledge in the pursuit of social justice work. Her philosophy recognizes that fundamentally our actions should 
always seek to maximize and enhance human wellbeing (Haight and Bidwell 2016; Hothersall 2019; Rosiek and Pratt 2013; Shields 2017) and draws a strong link between pragmatism and goals of social work research.

Both social work and pragmatism carry out the social problem-focused mission and share the person-in-environment perspective (Schilling 1997). Person-in-environment is a social work theoretical and practice perspective that suggests that we cannot understand persons fully without considering the various interactive aspects of their environmental contexts (Gray and Webb 2013). The person-in-environment concept is a main feature of pragmatism and can be traced back to Dewey's organism-in-environment perspective, which views humans as organism and knowledge as arising from an active adaptation of organism to their various environments-geographical, biological, social, political, and cultural. The focus of pragmatism is on the human capacity to learn, reason, and make choices in our environments; to respond to, and interact with, our environments; and to adapt to it, modify it, and shape it in various ways. These are constant, dynamic, and ongoing processes, and social work is concerned and particularly interested in these processes (Koenig et al. 2019; Thompson 2012). As a profession, social work has a long-standing declared focus on person-in-environment, so it is expected that social work plays a leadership role in research focused on understanding people and their environment (Zapf 2010). The primary focus of social work is not expected to be on psychological forces, environment, or social structures, but it is expected to be on the interface or relationship between people and their environments (Heinonen and Spearman 2015). As a paradigm, pragmatism offers an experience-based, action-oriented framework whereby the purpose of research is to help us address the issues of dealing with how we experience and come to know the world in a practical sense (Hothersall 2019). Therefore, a pragmatist understanding may offer theoretical insight to social work research (Koenig et al. 2019).

For professional social work, it is an appealing prospect to base practice on methodologically sound research evidence. Indeed, social work practitioners are increasingly being expected to work in an evidence-based culture. Due to the pressure to provide evidence that demonstrates the effectiveness of interventions and the call for social work professionals to be more accountable and transparent in their dealings, practitioners around the world are adopting evidence-based practice approaches (Alston and Bowles 2013; Engel and Schutt 2014; Faulkner and Faulkner 2009; Plath 2006, 2013; Smith 2004). The radix of evidence-based practice is believed to be medicine, which Gambrill (2006) describes as an "[evolving] philosophy and process designed to forward effective use of professional judgement in integrating information regarding each client's unique characteristics, circumstances, preferences, and actions and external research findings" (p. 339). Macdonald (2001), describes evidence-based practice as "an approach to decision-making which is transparent, accountable and based on the careful consideration of the most compelling evidence we have about the effects of particular interventions on the welfare of individuals, groups and communities" (p. xviii). There is a broad agreement that evidence-based practice ensures that professional practice is based on the best available knowledge of what should be considered as effective methods (Smith 2004). However, ever so often, due to practical problems such as limitations of time and resources, evidence-based practice is reduced to a "what works" or "what works best" approach (Plath 2006). Evidence-based practice is centered around effectiveness. To determine the effectiveness of an intervention, "social workers need to know 'what aspects worked well?', 'what aspects did not work well?', 'why?', 'for whom?', 'from whose perspective?', 'what were the relevant factors impacting on the situation?' and so on" (Plath 2006, p. 61). However, the effectiveness may vary depending upon the context and the standpoint of the person evaluating the intervention (Plath 2006).

On the other hand, in social work, evidence is described as socially constructed, value laden, and culture laden (Gibbs 2001; Webb 2001). For considering something as evidence, social workers rely on a range of information, experiences, and knowledge along with the hard facts (Alston and Bowles 2013; Plath 2006). In other words, the evidence base for social work needs to be strong, legitimate, and valuable. Although there have been debates about the appropriateness of different theoretical 
perspectives and research paradigms for evidence-based practice (Smith 2004), pragmatist perspectives are frequently found to be appropriate for social work (see Borden 2013; Chaumba 2013; Newman and McNeish 2005; Plath 2006; Shaw 1999, 2003; Smith 2004).

Since the start of the social work profession, a pragmatic attitude has been hailed as a defining feature of the profession's tradition. Most clinicians endorse eclecticism as their fundamental approach to practicing social work (Borden 2013). Pragmatism has also been suggested as a useful approach for identifying appropriate evidence for social workers needing to make informed decisions in practice (Plath 2013). Yet, social work research, done to determine the effectiveness of intervention and identify definitive evidence of effectiveness, has predominantly shown a preference for postpositivist approach, with quantitative experimental methods such as large randomized control trials, single system designs, or systematic reviews with meta-analysis of research experiments (see Gambrill 1999; Gibbs and Gambrill 2002; Kubiak et al. 2015; Lo et al. 2015; Macdonald 2001; Macdonald et al. 1992; Mullen 2002). Critics of this approach have argued that randomized control trials have little value outside of drug trials, particularly for addressing the intricacies of encounter with people, including the practitioners' understanding of the intervention process and their own role in that process (Eisler 2002; Reid 2001). The argument is that experimental designs are based on unrealistic hypothesis that are valid within limited contexts but may not be widely applicable in social work practice. Experimental designs are also disputed for reducing multidimensional problems into quantifiable and measurable variables (Plath 2006) and for isolating clients from their contexts (Holloway 2001).

Although the interpretivist approaches do not naturally fit with determining the effectiveness of intervention for evidence-based practice (Plath 2013), its proponents argue that we cannot ignore the role of interpretation and meaning in identifying and examining the evidence (Shaw 2003; Webb 2002). Narrative interviews are often argued to be a more appropriate approach to investigating social work questions because they offer the understanding of the importance of interventions in people's lives (Holloway 2001; Shaw 1999). Qualitative approaches are suggested as useful in understanding the nature, quality, and context of interventions (Hausman 2002; Bower and Rowland 2006). The complexity of arguments leads toward two general agreements. First, social research questions demand the most appropriate method from a range of different research methods. Second, both qualitative and quantitative, can contribute to the advancement of social work knowledge (Plath 2006). These arguments certainly assert pragmatism as an appropriate research paradigm for social work research, particularly for gathering evidence to determine the effectiveness of interventions. Pragmatism supports theory based on experience, experimentation, and action (Ormerod 2006). As a research paradigm, it allows the flexibility to choose various combinations of methods and to inquire from a variety of perspectives. Thus, in pragmatist research, observations, experience, and experiments are all useful ways to understand people and their world. Finally, pragmatism endorses eclecticism and pluralism and accepts different, even conflicting, theories and perspectives (Johnson and Onwuegbuzie 2004).

Another argument is that there is no point in examining the outcomes of interventions if we do not understand the processes involved in those interventions (Cheetham 1992). To inform and justify professional practice, social work researchers need to identify and supply a range of evidence for effective interventions. A pragmatist approach fits closely with this objective as it allows researchers to gather evidence from a range of sources and to critically evaluate them in terms of their strengths, limitations, and applicability to the practice setting (Plath 2013). The pragmatist worldview helps in bringing together scientific and humanistic domains of understanding. It assists practitioners to focus their attention on essential concerns in active practice situations. Besides, practitioners can use the conceptions of pragmatism as orienting perspectives for critical thinking and decision making in real-life practice situations (Borden 2013). Pragmatism never considers knowledge as final, universal, or absolute. For pragmatists, knowledge is never finished or perfect as it stands. Instead, knowledge is always in a process that can be revised and improved. This permits social work researchers great critical thinking opportunities for analyzing and synthesizing extant knowledge while at the same time exploring the possibilities of inventing new knowledge. In sum, it allows researchers to utilize 
wisdom, ideas, and expertise from practitioners as well as clients to advance ideas, address research goals, and create socially useful knowledge (Feilzer 2010; Koenig et al. 2019; Thompson 2012).

Taking into consideration all justifications for the pragmatic approach, we suggest that pragmatism has the potential to offer an organizing framework for social work research. Unlike more positivistic or constructivist models of research, a pragmatic model allows for a plurality of views and methods to be a part of its overall research plan. A pragmatic lens presents a real alternative that can be developed and utilized for social work research (Borden 2010; Hothersall 2019). The newer social work literature also acknowledges the significance and value of pragmatism as a research paradigm to address the research needs of the social work profession (see Hardy 2016; Hothersall 2017; Kolly 2017; Koenig et al. 2019; Lushin and Anastas 2011; Yan 2013). Several other studies that are not in the field of social work have adopted pragmatism as the research paradigm. Nevertheless, these studies inform social work profession and social work research (see Aiken and Talisse 2016; Ansell and Boin 2017; Ellingsen et al. 2014; Gross 2018; Paulus 2017; Sherman et al. 2016).

\section{Pragmatism and Social Justice}

There is a strong fit between pragmatism and advocacy of social justice (Morgan 2014b). Pragmatists have always had a deep sense of justice. They are deeply aware of the suffering of people and of the need to build just institutions. They are constantly involved in a "search for a tolerant and nondiscriminatory culture that regards all people with equal concern and respect" (Dieleman et al. 2017, p. 2). As a paradigm, pragmatism grapples with analyzing contemporary social issues and engages with themes of social inequality, power, and politics (Collins 2017). Pragmatism has always appealed to activists who have found in it a movement within which they could work for a new social order (Seigfried 1996). Pragmatism focuses on meaningful research, which for early pragmatists began with the desire for a better world (Wolfe 1999). What appealed to pragmatists was the concern with the social issues and its practical decision-making processes attached to research aimed at improving social problems combined with its ethical basis of "the greatest good for the greatest number" (Maxcy 2003, p. 55). Pragmatist philosophy views inquiry as a natural part of life aimed at improving our condition by adaptation and accommodations in the social world in which we live (Cronen 2001). Inquiry is rooted in humans' ordinary initiatives for betterment. Pragmatism has an interest for what the world might be-it orients itself toward a prospective world, a world not yet realized. The primary goal of pragmatism is to create practical knowledge that has utility for action for making purposeful difference in practice (Goldkuhl 2012).

Dewey (1954) advocates for an inquiry in which individuals and communities are able to identify the issues that matter most to them, define those issues, and pursue them in ways that are the most meaningful to them. Dewey's version of inquiry emphasizes the capacity for growth. He opposes any use of force or economic hegemony that may limit the opportunities for growth of other social groups (Morgan 2014b). Likewise, Dewey's version of democracy calls upon people to build communities that make necessary opportunities and resources available for each individual such that they fully realize their capacities and potentials through participation in political, social, and cultural life (Westbrook 1991). Taken together, pragmatism promotes a problem-solving, action-oriented process of inquiry which is based on democratic values and commitment to progress (Biesta 2010; Greene and Hall 2010; Johnson and Onwuegbuzie 2004). Pragmatists focus on democracy and on the processes of participatory democracy to create democratic communities (Collins 2017). This establishes a natural connection between pragmatism and social justice research on issues such as equity, fairness, and freedom from oppression.

Pragmatist inquiry has a broad view of the initial experiential material to be analyzed. It does not limit itself to experiential resources produced by empirical research and scientific studies and risk not capturing those aspects of social injustices that may not be easily captured through scientific inquiry. Pragmatists approach problems of injustices by utilizing empirical research and first-order experiences together in an effort to identify problems that persist in society and to develop solutions to address those 
problems. A pragmatic approach allows the possibility of choosing the appropriate research methods from the wide range of qualitative and/or quantitative methods, and this pluralism is a strength of pragmatism that has several advantages for social justice research. It sets an inclusive framework of inquiry that supports interdisciplinary and cooperative research about social injustices (Pappas 2017). For instance, possibility for generalization of findings due to wide and representative sampling within marginalized populations; analysis of cause-and-effect relationships among social justice constructs; creation of theory on the oppressive conditions facing marginalized groups and verification of it by confirming or disconfirming hypotheses generated from existing theories relevant for social justice research (abduction); increased depth and confidence in interpretation of findings related to oppressive conditions; reinforcement of small sample, in-depth interview or observation findings by documenting the representativeness' of oppressive conditions in larger representative samples; or rephrasing of the research questions on the oppressive phenomenon after reflecting on it (Dewey's five-step model) (see Desimone 2009; Greene 2007; Johnson and Onwuegbuzie 2004; Leech and Onwuegbuzie 2010; Ponterotto et al. 2013). In sum, pragmatists do not hold the assumption that their approach involves the ultimate political perspective, true social theory, or the best knowledge-generating method. Instead, they start with an ethics-based pursuit of democracy, equality, justice, and freedom for everyone (Koenig et al. 2019).

\section{Conclusions}

"Any problem of scientific inquiry that does not grow out of actual (or 'practical') social conditions is factitious; it is arbitrarily set by the inquirer" (Dewey 1938, p. 499).

Methodological traditions are similar to any other social phenomena in that they are made by people who work together and criticize one another. Just like social phenomena, methodological traditions also borrow from other traditions (Abbott 2004, p. 15). As a result, research paradigms are subject of continuous debate and critique, and through these debates, researchers find new insights to make genuine contributions (Lystbæk 2018). "Paradigmatic critique is useful heuristically" (Abbott 2004, p. 76). Specific ways of thinking and working in research functions as heuristics-there can be several ways of doing research, and each way can be used to solve several problems in research. To recognize the importance of the basic assumptions of a particular research paradigm does not mean that those assumptions are isolated, that they constitute a unitary and coherent pattern, or that they can easily be integrated. It does not mean that a paradigm should be perceived as a logically consistent and unified systems of thought (Abbott 2001, 2004; Lystbæk 2018; Maxwell 2011). Attention to the philosophical assumptions of paradigms is critically important to social research, because those assumptions guide our decisions as researchers, but it is also important to note that social inquiries are shaped and molded by more unified than the abstract philosophical assumptions. The topic of the social inquiry, the analyses, and the interpretation of the data are also influenced by disciplinary ways of thinking; by researcher's favored theories, professional and personal life experience, and values; by the dynamics of the context; by political factors; and more (Greene and Hall 2010).

In this article, our intention was to highlight pragmatism as a research paradigm that holds value for social justice research. In bringing together a variety of perspectives, we argue that pragmatism has the potential to closely engage and empower marginalized and oppressed communities and provides hard evidence for micro- to macro-level discourse. By providing insights into particular considerations, we assert that social researchers can mobilize to inform their investigations. While this discussion is not intended to be exhaustive, it does bring together the critical literature that speaks about pragmatism as a research paradigm and its implication for social work research. Future writers can continue to synthesize research on this topic, typically the ones that promote or argue against the use of pragmatism as a research paradigm for social work and social justice-oriented research.

Author Contributions: Conceptualization, V.K.; formal analysis, V.K.; investigation, V.K.; writing-original draft, V.K.; writing一review \& editing, V.K. and C.A.W. 
Funding: This research received no external funding.

Conflicts of Interest: The authors declare no conflict of interest.

\section{References}

Abbott, Andrew. 2001. Chaos of Disciplines. Chicago: University of Chicago Press.

Abbott, Andrew. 2004. Methods of Discovery: Heuristics for the Social Sciences. New York: W. W. Norton.

Aiken, Scott F., and Robert B Talisse. 2016. Pragmatism and pluralism revisited. Political Studies Review 14: 17-26. [CrossRef]

Alston, Margaret, and Wendy Bowles. 2013. Research for Social Workers: An Introduction to Methods, 3rd ed. Abingdon: Routledge.

Ansell, Chris, and Arjen Boin. 2017. Taming deep uncertainty: The potential of pragmatist principles for understanding and improving strategic crisis management. Administration E Society 51: 1079-112.

Baker, Max, and Stefan Schaltegger. 2015. Pragmatism and new directions in social and environmental accountability research. Accounting, Auditing and Accountability Journal 28: 263-94. [CrossRef]

Betzner, Anne E. 2008. Pragmatic and Dialectic Mixed Method Approaches: An Empirical Comparison. Ph.D. dissertation, University of Minnesota, Minneapolis, MN, USA. Unpublished.

Biesta, Gert. 2010. Pragmatism and the philosophical foundations of mixed methods research. In Handbook of Mixed Methods in Social and Behavioral Research, 2nd ed. Edited by Abbas Tashakkori and Charles Teddlie. Thousand Oaks: Sage, pp. 95-117.

Boisvert, Raymond D. 1998. John Dewey: Rethinking Our Time. Albany: State University of New York.

Borden, William. 2010. Taking multiplicity seriously: Pluralism, pragmatism, and integrative perspectives in clinical social work. In Reshaping Theory in Contemporary Social Work: Toward a Critical Pluralism in Clinical Practice. Edited by William Borden. New York: Columbia University Press, pp. 3-27.

Borden, William. 2013. Experiments in adapting to need: Pragmatism as orienting perspective in clinical social work. Journal of Social Work Practice 27: 259-71. [CrossRef]

Bower, Peter J., and Nancy Rowland. 2006. Effectiveness and cost effectiveness of counselling in primary care. The Cochrane Database of Systematic Reviews 3: CD001025.

Bryman, Alan. 2006. Paradigm peace and the implications of quality. International Journal of Social Research Methodology 9: 111-26. [CrossRef]

Chaumba, Josphine. 2013. The use and value of mixed methods research in social work. Advances in Social Work 14: 307-33. [CrossRef]

Cheetham, Juliet. 1992. Evaluating social work effectiveness. Research on Social Work Practice 2: 265-87. [CrossRef]

Collins, Patricia Hill. 2017. Social inequality, power, and politics: Intersectionality in Dialogue with American Pragmatism. In Pragmatism and Justice. Edited by Susan Dieleman, David Rondel and Christopher Voparil. New York: Oxford University Press, pp. 147-62.

Creswell, John W. 2009. Research Design: Qualitative, Quantitative, and Mixed Methods Approach, 3rd ed. Thousand Oaks: Sage.

Creswell, John W. 2013. Qualitative Inquiry and Research Design: Choosing among Five Approaches, 3rd ed. Thousand Oaks: Sage.

Creswell, John W., and Vicki L. Plano Clark. 2011. Designing and Conducting Mixed Methods Research, 2nd ed. Thousand Oaks: Sage.

Cronen, Vernon E. 2001. Practical theory, practical art, and the pragmatic-systemic account of inquiry. Communication Theory 11: 14-35. [CrossRef]

Deen, Phillip. 2011. Herbert Marcuse's “Review of John Dewey's logic: The theory of inquiry. Transactions of the Charles S. Peirce Society 46: 258-65.

Desimone, Laura M. 2009. Improving impact studies of teachers' professional development: Toward better conceptualizations and measures. Educational Researcher 38: 181-99. [CrossRef]

Dewey, John, ed. 1931. The development of American pragmatism. In Philosophy and Civilization. New York: Minton, Balch and Co.

Dewey, John. 1933. How We Think: A Restatement of the Relation of Reflective Thinking to the Educative Process. Boston: Heath.

Dewey, John. 1938. Logic: The Theory of Inquiry. New York: Henry Holt. 
Dewey, John. 1954. The Public and Its Problems. Chicago: Swallow Press.

Dieleman, Susan, David Rondel, and Christopher Voparil. 2017. Introduction: Perspectives on pragmatism and justice. In Pragmatism and Justice. Edited by Susan Dieleman, David Rondel and Christopher Voparil. New York: Oxford University Press, pp. 1-17.

Dillon, Deborah R., David G. O'Brien, and Elizabeth E. Heilman. 2000. Literacy research in the next millennium: From paradigms to pragmatism and practicality. Reading Research Quarterly 35: 10-26. [CrossRef]

Eisler, Ivan. 2002. Comment: the scientific practitioner and family therapy: A way forward, a strait-jacket or a distraction? Journal of Family Therapy 24: 125-33. [CrossRef]

Ellingsen, Ingunn T., Arlene Arstand Thorsen, and Ingunn Størksen. 2014. Revealing children's experiences and emotions through Q methodology. Child Development Research. [CrossRef]

Engel, Rafael J., and Russel K. Schutt. 2014. Fundamentals of Social Work Research, 2nd ed. Los Angeles: Sage.

Erzberger, Christian, and Udo Kelle. 2003. Making inferences in mixed methods: The rules of integration. In Handbook of Mixed Methods in Social and Behavioral Research. Edited by Abbas Tashakkori and Charles Teddlie. Thousand Oaks: Sage, pp. 457-88.

Faulkner, Samuel S., and Cynthia A. Faulkner. 2009. Research Methods for Social Workers: A Practice-Based Approach. Chicago: Lyceum Books Inc.

Feilzer, Martina Yvonne. 2010. Doing mixed methods research pragmatically: Implications for the rediscovery of pragmatism as a research paradigm. Journal of Mixed Methods Research 4: 6-16. [CrossRef]

Frega, Roberto. 2011. Introduction. In Pragmatist Epistemologies. Edited by Roberto Frega Lanham. Washington: Lexington Books, pp. 1-4.

Gambrill, Eileen. 1999. Evidence-based practice: An alternative to authority-based practice. Families in Society 80: 341-50. [CrossRef]

Gambrill, Eileen. 2006. Evidence-based practice and policy: Choices ahead. Research on Social Work Practice 16: 338-57. [CrossRef]

Gibbs, Anita. 2001. The changing nature and context of social work research. British Journal of Social Work 31: 687-704. [CrossRef]

Gibbs, Leonard, and Eileen Gambrill. 2002. Evidence-based practice: Counterarguments to objections. Research on Social Work Practice 12: 452-76. [CrossRef]

Goldkuhl, Göran. 2012. Pragmatism vs interpretivism in qualitative information systems research. European Journal of Information Systems 21: 135-46. [CrossRef]

Goles, Tim, and Rudy Hirschheim. 2000. The paradigm is dead, the paradigm is dead ... long live the paradigm: the legacy of Burrell and Morgan. Omega: The International Journal of Management Science 28: 249-68. [CrossRef]

Gray, Mel, and Stephen Webb. 2013. Social Work Theories and Methods. London: SAGE Publications.

Greene, Jennifer C. 2007. Mixing Methods in Social Inquiry. San Francisco: Jossey-Bass.

Greene, Jennifer C., and Valerie J. Caracelli. 2003. Making paradigmatic sense of mixed methods practice. In Handbook of Mixed Methods in Social and Behavioral Research. Edited by Abbas Tashakkori and Charles Teddlie. Thousand Oaks: Sage, pp. 91-110.

Greene, Jennifer C., and Jori N. Hall. 2010. Dialectics and pragmatism: Being of consequence. In Handbook of Mixed Methods in Social and Behavioral Research, 2nd ed. Edited by Abbas Tashakkori and Charles Teddlie. Thousand Oaks: Sage, pp. 113-43.

Gross, Neil. 2018. Pragmatism and the study of large-scale phenomena. Theory and Society 47: 87-111. [CrossRef] Haight, Wendy, and Laurel N. Bidwell. 2016. Mixed Methods Research for Social Work. Chicago: Lyceum Books Inc.

Hardy, Mark. 2016. 'I know what I like and I like what I know': Epistemology in practice and theory and practice again. Qualitative Social Work 15: 762-78. [CrossRef]

Hausman, Alice J. 2002. Implications of evidence-based practice for community health. American Journal of Community Psychology 30: 149-66. [CrossRef]

Heinonen, Tuula, and Len Spearman. 2015. Social Work Practice: Problem Solving and Beyond. Vancouver: Langara College.

Holloway, Wendy. 2001. The psycho-social subject in 'evidence based practice'. Journal of Social Work Practice 15: 10-21. [CrossRef]

Hothersall, Steve J. 2017. “Everyday knowledge': A mixed-methods study using factor analysis and narrative approaches to explore social worker's knowledge'. Social Work and Social Sciences Review 19: 33-64. 
Hothersall, Steve J. 2019. Epistemology and social work: enhancing the integration of theory, practice and research through philosophical pragmatism. European Journal of Social Work. [CrossRef]

Howe, Kenneth R. 1988. Against the quantitative-qualitative incompatibility thesis or dogmas die hard. Educational Researcher 17: 10-16. [CrossRef]

James, William. 2000. What pragmatism means. In Pragmatism and the Classical American Philosophy: Essential Readings and Interpretive Essay, 2nd ed. Edited by John J. Stuhr. New York: Oxford University Press, pp. 193-202.

Johnson, R. Burke, and Anthony J. Onwuegbuzie. 2004. Mixed methods research: A research paradigm whose time has come. Educational Researcher 33: 14-26. [CrossRef]

Koenig, Terry, Rick Spano, and John Thompson. 2019. Human Behavior Theory for Social Work Practice. Singapore: Sage Publications.

Kolly, Maryam. 2017. A pragmatic approach to social work. Canadian Journal of Family and Youth 10: $455-73$. [CrossRef]

Kubiak, Sheryl Pimlott, Woo Jong Kim, Gina Fedock, and Deborah Bybee. 2015. Testing a violence-prevention intervention for incarcerated women using a randomized control trial. Research on Social Work Practice 25: 334-48. [CrossRef]

Kuhn, Thomas S. 1962. The Structure of Scientific Revolutions. Chicago: University of Chicago Press.

Kuhn, Thomas S. 1970. The Structure of Scientific Revolutions, 2nd ed. Chicago: University of Chicago Press.

Lanham, Chong Ho Yu. 2006. Philosophical Foundations of Quantitative Research Methodology. Lanham: University Press of America.

Leech, Nancy L., and Anthony J. Onwuegbuzie. 2010. Guidelines for conducting and reporting mixed research in the field of counseling and beyond. Journal of Counseling and Development 68: 61-69. [CrossRef]

Lincoln, Yvonne. 1990. The making of a constructivist: A remembrance of transformations past. In The Paradigm Dialog. Edited by Egon G. Guba. Newbury Park: Sage, pp. 67-87.

Lincoln, Yvonne, Susan A. Lynham, and Egon G. Guba. 2011. Paradigms and perspectives in contention. In The Sage Handbook of Qualitative Research. Edited by Norman K. Denzin and Yvonna S. Lincoln. Thousand Oaks: Sage Publications, pp. 91-95.

Lo, Herman H. M., Siu Man Ng, and Cecilia L. W. Chan. 2015. Evaluating compassion-mindfulness therapy for recurrent anxiety and depression: A randomized control trial. Research on Social Work Practice 25: 715-25. [CrossRef]

Lushin, Victor, and Jeane W. Anastas. 2011. Harm reduction in substance abuse treatment: Pragmatism as an epistemology for social work practice. Journal of Social Work Practice in the Addictions 11: 96-100. [CrossRef]

Lystbæk, Christian. 2018. Towards Evidence-Reflected Practice: Paradigms as Heuristics in Business Research. Kidmore End: Academic Conferences International Limited. Available online: http://ezproxy.lib.ucalgary. ca/login?url=https://search-proquest-com.ezproxy.lib.ucalgary.ca/docview $/ 2088045441$ ?accountid=9838 (accessed on 1 July 2019).

Macdonald, Geraldine. 2001. Effective Interventions for Child Abuse and Neglect: An Evidence-Based Approach to Planning and Evaluating Interventions. Chichester: Wiley.

Macdonald, Geraldine, Brian Sheldon, and Jane Gillespie. 1992. Contemporary studies of the effectiveness of social work. British Journal of Social Work 22: 615-43.

Maxcy, Spencer J. 2003. Pragmatic threads in mixed methods research in the social sciences: The search for multiple modes of inquiry and the end of the philosophy of formalism. In Handbook of Mixed Methods in Social and Behavioral Research. Edited by Abbas Tashakkori and Charles Teddlie. Thousand Oaks: Sage, pp. 51-89.

Maxwell, Joseph A. 2011. Paradigms or toolkits? Philosophical and methodological positions as heuristics for mixed methods research. Mid-Western Educational Researcher 24: 27-30.

Maxwell, Joseph A., and Kavita Mittapalli. 2010. Realism as a stance for mixed methods research. In SAGE Handbook of Mixed Methods in Social and Behavioral Research, 2nd ed. Edited by A. Tashakkori and Charles Teddlie. Thousand Oaks: Sage, pp. 145-68.

Mcgilvary, Evander Bradley, G. Watts Cunningham, C. I. Lewis, and Ernest Nagel. 1939. A symposium of reviews of John Dewey's logic: The theory of inquiry. The Journal of Philosophy 36: 561-81. [CrossRef]

Morgan, David L. 2007. Paradigms lost and pragmatism regained: Methodological implications of combining qualitative and quantitative methods. Journal of Mixed Methods Research 1: 48-76. [CrossRef]

Morgan, David L. 2014a. Integrating Qualitative and Quantitative Methods: A Pragmatic Approach. Thousand Oaks: Sage. 
Morgan, David. L. 2014b. Pragmatism as a paradigm for social research. Qualitative Inquiry 20: 1045-53. [CrossRef] Mullen, Edward. 2002. Evidence-Based Social Work Theory and Practice: Historical and Reflective Perspective. Paper Presented at the 4th International Conference on Evaluation for Practice, University of Tampere, Tampere, Finland, July 4-6.

Newman, Tony, and Di McNeish. 2005. Promoting evidence-based practice in a child care charity: The Barnardo's experience. In Evidence-Based Practice in Social Work. Edited by Andy Bilson. London: Whiting and Birch, pp. 176-89.

Ormerod, Richard J. 2006. The history and ideas of pragmatism. The Journal of the Operational Research Society 57: 892-909. [CrossRef]

Pansiri, Jaloni. 2005. Pragmatism: A methodological approach to researching strategic alliances in tourism. Tourism and Hospitality Planning and Development 2: 191-206. [CrossRef]

Pappas, Gregory Fernando. 2017. Empirical approaches to problems of injustices: Elizabeth Anderson and the Pragmatists. In Pragmatism and Justice. Edited by Susan Dieleman, David Rondel and Christopher Voparil. New York: Oxford University Press, pp. 81-96.

Patton, Michael Quinn. 2002. Qualitative Research and Evaluation Methods, 3rd ed. Thousand Oaks: Sage Publications.

Paulus, Martin P. 2017. Evidence-Based pragmatic psychiatry-A call to action. Journal of the American Medical Association Psychiatry 74: 1185-86. [CrossRef] [PubMed]

Plath, Debbie. 2006. Evidence-based practice: Current issues and future directions. Australian Social Work 59: 56-72. [CrossRef]

Plath, Debbie. 2013. Evidence-based practice. In Social Work Theories and Methods, 2nd ed. Edited by Mel Gray and Stephen Webb. London: Sage, pp. 229-40.

Ponterotto, Joseph G., Jaya T. Mathew, and Brigid Raughley. 2013. The value of mixed methods designs to social justice research in counseling and psychology. Journal for Social Action in Counseling and Psychology 5: 42-68.

Ray, Larry. 2004. Pragmatism and critical theory. European Journal of Social Theory 7: 307-21. [CrossRef]

Reid, William J. 2001. The role of science in social work: The perennial debate. Journal of Social Work 1: $273-93$. [CrossRef]

Robson, Colin. 1993. Real World Research. Oxford: Blackwell.

Rorty, Richard. 1980. Pragmatism, relativism and irrationalism. Proceedings and Addresses of the American Philosophical Association 53: 719-38. [CrossRef]

Rorty, Richard. 2000. Philosophy and Social Hope. London: Penguin Books.

Rosiek, Jerry Lee, and Scott Pratt. 2013. Jane Addams as a resource for developing a reflexively realist social science practice. Qualitative Inquiry 19: 578-88. [CrossRef]

Rossman, Gretchen B., and Sharon F. Rallis. 2003. Learning in the Field: An Introduction to Qualitative Research, 2nd ed. Thousand Oaks: Sage Publications.

Schilling, Robert F. 1997. Developing intervention research programs in social work. Social Work Research 21 : 173-80. [CrossRef]

Seigfried, Charlene Haddock. 1996. Pragmatism and Feminism: Reweaving the Social Fabric. Chicago: The University of Chicago Press.

Shaw, Ian. 1999. Evidence for practice. In Evaluation and Social Work Practice. Edited by Ian Shaw and Joyce Lishman. London: Sage Publications, pp. 14-40.

Shaw, Ian. 2003. Cutting edge issues in social work research. British Journal of Social Work 33: 107-20. [CrossRef]

Sherman, Rachel E., Steven A. Anderson, Gerald J. Dal Pan, Gerry W. Gray, Thomas Gross, Nina L. Hunter, Lisa LaVange, Danica Marinac-Dabic, Peter W. Marks, Melissa A. Robb, and et al. 2016. Real-World evidence-What Is It and what Can It tell Us? New England Journal of Medicine 375: 2293-97. [CrossRef] [PubMed]

Shields, Patricia M., ed. 2017. Jane Addams: Progressive Pioneer of Peace, Philosophy, Sociology, Social Work and Public Administration. Cham: Springer.

Smith, David. 2004. Social Work and Evidence-Based Practice. London: Jessica Kingsley Publishers.

Tashakkori, Abbas, and Charles Teddlie. 1998. Mixed Methodology: Combining Qualitative and Quantitative Approaches. Applied Social Research Methods Series, 46; Thousand Oaks: Sage Publications.

Tashakkori, Abbas, and Charles Teddlie. 2008. Mixed Methodology: Combining Qualitative and Quantitative Approaches. Thousand Oaks: Sage Publications. 
Teddlie, Charles, and Abbas Tashakkori. 2003. Major issues and controversies in the use of mixed methods in the social and behavioural sciences. In Handbook of Mixed Methods in Social and Behavioral Research. Edited by Abbas Tashakkori and Charles Teddlie. Thousand Oaks: Sage Publications, pp. 3-50.

Teddlie, Charles, and Abbas Tashakkori. 2009. Foundations of Mixed Methods Research. Thousand Oaks: Sage Publications.

Thompson, Audrey. 1997. Political pragmatism and educational inquiry. In Philosophy of Education. Edited by Frank Margonis. Urbana: Philosophy of Education Society, pp. 425-34.

Thompson, John Brandon. 2012. Rethinking the Clinical vs. Social Reform Debate: A Dialectical Approach to Defining Social Work in the 21st Century. Ph.D. dissertation, University of Kansas, Lawrence, KS, USA, May 1.

Webb, Stephen A. 2001. Some consideration on the validity of evidence-based practice in social work. British Journal of Social Work 31: 57-59. [CrossRef]

Webb, Stephen A. 2002. Evidence-based practice and decision analysis in social work: An implementation model. Journal of Social Work 2: 45-63. [CrossRef]

Westbrook, Robert B. 1991. John Dewey and American Democracy. Ithaca: Cornell University Press.

Wolfe, Alan. 1999. The missing pragmatic revival in American social science. In The Revival of Pragmatism: New Essays on Social Thought, Law, and Culture. Edited by Morris Dickstein. Durham: Duke University Press, pp. 199-206.

Yan, Miu Chung. 2013. Towards a pragmatic approach: A critical examination of two assumptions of indigenization discourse. China Journal of Social Work 6: 14-24. [CrossRef]

Yefimov, Vladimir. 2004. On Pragmatist Institutional Economics. IDEAS Working Paper Series from RePEc; Munich: Munich Personal RePEc Archive.

Zapf, Michael Kim. 2010. Social work and the environment: Understanding people and place. Critical Social Work 11: 30-46.

(C) 2019 by the authors. Licensee MDPI, Basel, Switzerland. This article is an open access article distributed under the terms and conditions of the Creative Commons Attribution (CC BY) license (http://creativecommons.org/licenses/by/4.0/). 